\title{
Pengaruh Program Reality Show Kepolisian terhadap Sikap Penonton di Jakarta
}

\author{
Panji Andika Raspati", Endang Setiowati \\ Fakultas Ilmu Komunikasi, Sekolah Tinggi Ilmu Komunikasi Inter Studi \\ *Praspati@yahoo.com, Setiowati@gmail.com
}

\begin{abstract}
Every television program consumed by the audience will have an impact on the audience, including the formation of audience attitudes about the issues presented by the program. This study aims to determine the audience's attitude about traffic signs, after consuming the Police reality show program entitled "86" which airs on Net television station every day at 21.30 WIB. To analyze the research results, social cognitive theory is used which discusses how audiences learn from media content. There are two concepts used which are also variables, the X variable, namely the "86" Reality Show Program and the concept of the attitude which is the $\mathrm{Y}$ variable, namely the Attitude of the Audience. The paradigm of this research is positivistic, with a quantitative approach, and this research method is in the form of a survey. The total sample of 100 respondents was taken using convenience sampling technique, namely by distributing 100 questionnaires to motorbikes and cars drivers in Jakarta. The results of the research, there is a significant influence from the Reality Show Program "86" on NET. to the Attitude of the Audience in Jakarta. This research also shows a very strong relationship between the Reality Show program "86" on NET. with the Attitude of the Audience in Jakarta. The academic implication of this research is that it can provide additional knowledge about the application of Social Cognitive theory in reality show program on television. While the practical implication is that it can be an input for broadcasting practitioners in making programs that are useful for changes in audience attitudes.
\end{abstract}

Keywords: Reality Show, Audience Attitude, Observational Learning Effect, Response Effec

Abstrak. Setiap program televisi yang tayang dan dikonsumsi khalayak akan memberi dampak pada khalayak, antara lain terbentuknya sikap khalayak tentang isu yang disampaikan program tersebut, Penelitian ini bertujuan untuk mengetahui Sikap Penonton tentang rambu lalulintas, setelah mengonsumsi program reality show Kepolisian berjudul "86" yang tayang di stasiun televisi Net. setiap hari pada pukul 21.30 WIB. Untuk menganalisis hasil penelitian digunakan teori kognitif sosial yang membahas bagaimana khalayak belajar dari isi media. Terdapat dua konsep yang digunakan yang juga merupakan variabel, variabel $\mathrm{X}$ yaitu Program Reality Show "86" dan konsep Sikap yang menjadi variabel Y yaitu Sikap Penonton, Paradigma penelitian ini adalah Positivistik, dengan pendekatan kuantitatif, dan metode penelitian ini berbentuk Survey. Jumlah sampel sebanyak 100 orang responden yang diambil dengan menggunakan teknik pengambilan sampel convenience sampling yaitu dengan cara membagikan 100 kuesioner kepada pengendara motor maupun mobil di Jakarta. Berdasarkan hasil penelitian, terdapat pengaruh yang signifikan dari Program Reality Show "86" di NET. terhadap Sikap Penonton di Jakarta. Penelitian ini juga memperlihatkan hubungan yang sangat kuat antara program Reality Show "86" di NET. dengan Sikap Penonton di Jakarta. Implikasi akademis dari penelitian ini adalah dapat menjadi tambahan pengetahuan tentang penerapan teori Kognitif Sosial dalam program reality show di televisi. Sememntara implikasi praktisnya adalah dapat menjadi masukan bagi para praktisi penyiaran dalam membuat program yang berguna bagi perubahan sikap penonton.

Kata Kunci: Reality Show, Sikap Penonton, Observational Learning Effect, Response Effects 


\section{A. Pendahuluan}

Televisi merupakan media yang paling efektif untuk memberikan informasi kepada khalayak dan sangat berpengaruh saat ini (Gunsyahputra, 2020)

Televisi merupakan media masa yang menyalurkan gambar diam maupun bergerak serta suara melalui gelombang elektrik serta mengkonversikan kembali ke dalam cahaya yang bisa dipandang dan suara yang bisa didengar (Arafat, 2021)

Stasiun televisi banyak menyuguhkan berbagai macam jenis program yang banyak dan beragam. Apa saja bisa dijadikan program televisi selama program tersebut diminati dan program itu menarik bagi audiens, selama program tersebut tidak bertentangan dengan nilai kesusilaan, hukum dan peraturan yang berlaku (Morissan, 2018).

Program televisi merupakan faktor utama dalam mendukung finansial suatu penyiar radio dan televisi adalah program yang bisa membuat audiens mengenal suatu penyiar. Berbagai macam jenis program televisi dapat dibagi menjadi beberapa jenis, yaitu program berita yang terdiri dari hard news, soft news, serta program hiburan yang terdiri dari drama termasuk sinetron dan film, permainan (game show), reality show, musik dan pertunjukan (Morissan, 2018).

Dalam penelitian ini akan diteliti salah satu program reality show yang bertema kepolisian yaitu program Reality Show "86" yang tayang stasiun televisi NET.. Program Reality Show merupakan program yang berisi suatu kejadian yang nyata tanpa rekayasa. Dengan kata lain, program yang menyajikan situasi sebagaimana apa adanya seperti situasi konflik, hubungan berdasarkan dengan sebuah realitas sebenarnya atau persaingan (Fachruddin, 2015).

Program Reality Show 86 yang tayang di NET. menyuguhkan adegan-adegan yang mengandung unsur adrenalin seperti adegan penggerebekkan sarang narkotika, ataupun adegan polantas yang menilang pengendara yang melanggar lalu lintas. Salah satu segmen yang selalu ada dalam program ini adalah segmen lalu lintas di mana disajikan adegan pelanggaran lalu lintas yang kemudian pelanggarnya ditilang, juga ditampilkan adegan pengendara yang tertib lalu lintas dan dijadikan contoh yang baik atau mendapat pujian.

Program Reality Show "86" di NET. ini tayang setiap hari pada pukul 21.30 WIB yang berdurasi 60 menit. Program ini memiliki slogan "Melindungi, Mengayomi, Melayani" yang akan diingat oleh Khalayak. Khalayak diajak untuk mengetahui sisi lain dari pihak kepolisian dalam bertugas untuk mengamankan kejadian di lapangan. (Darajat, 2017).

Hal ini bertujuan untuk mengenalkan kepada penonton bahwa tugas polisi adalah melindungi dan mengyomi serta memberikan informasi kepada penonton bahwa pentingnya berkendara dengan tertib. Program " 86 " di NET. Ini sekaligus memberikan kesadaran bahwa pentingnya mematuhi peraturan Negara dengan cara mendisiplinkan diri sendiri (Andriyarini, 2014).

Program "86" ini sangat menekankan edukasi terhadap masyarakat yang menonton. Sebagai contoh pada episode "Operasi Zebra, Anggota Polres Jakpus Razia Kendaraan Plat Ganjil Genap". Dalam episode ini ditayangkan adegan kejadian langsung di lapangan dimana seorang petugas bernama Bripda Tiara dari Korlantas Polri memberhentikan seorang pengemudi mobil box berplat nomor genap yang melintas di jalan yang melarang mobil berplat nomor genap melintas karena hari itu adalah tanggal ganjil. Di dalam adegan itu Sang supir berdalih ia tidak mengetahui apa kesalahannya, ketika sepengetahuannya jam 06.00 hingga 10.00 WIB adalah jam yang diperbolehkan melintas semua plat ganjil dan genap. Padahal dalam aturan justru pada jam $06.00-10.00$ WIB \& $16.00-20.00$ WIB adalah jam yang dikhususkan hanya kendaraan yang berplat nomor sesuai dengan tanggal itu untuk melintas di jalan. Meski berdalih tidak tahu, polisi dengan tegas menilang sang pengemudi.

Program ini tidak saja memberitahu penonton tentang aturan-aturan lalu lintas yang berlaku namun juga mengedukasi penonton untuk lebih mendapatkan wawasan atau pengetahuan dalam mengenal peraturan rambu lalu lintas. Selain itu, dengan menonton program 86 ini, sikap masyarakat yang sering melanggar rambu lalu lintas, dapat berubah karena memahami resiko yang akan didapatnya, bukan saja karena akan kena tilang tapi juga resiko lain seperti kecelakaan lalu lintas akibat melanggar aturan lalu lintas.

Dari pernyataan di atas, tampak terlihat manfaat menonton program " 86 " di NET. 
adalah untuk memberikan pengetahuan pada masyarakat dapat meningkatkan kedisiplinan dalam mematuhi peraturan negara. Selain itu program Reality Show "86" ini juga bisa menjadi semacam sosialisasi yang sangat efektif mengenai aturan-aturan berlalu lintas hingga sanksi yang didapat bila melakukan pelanggaran. Jadi, tidak ada alasan untuk warga yang tidak mengetahui suatu aturan (Lumbanraja, 2014).

Peneliti berasumsi bahwa di Jakarta yang terkenal akan kemacetannya, dikarenakan akibat dari pengguna kedaraan pribadi yang terlalu banyak. Maka tak heran ada saja masyarakat yang tidak mematuhi rambu-rambu lalu lintas agar cepat sampai tujuan. Beberapa sikap pengendara motor maupun pengemudi mobil di Jakarta sangat buruk. Seperti melawan arus, berhenti melebihi garis batas berhenti di lampu merah, melintas di jalur busway, tidak memakai helm, atribut tidak lengkap, dan lain-lain. Sikap tersebut sudah jelas berlawanan dari kata "taat peraturan dalam berkendara di jalan" (Sindo, 2015).

Contoh pelanggaran lalu lintas tersebut masuk ke dalam program Reality Show " 86 " di NET. Segmen penertiban lalu lintas. Oleh sebab itu, jika seseorang menonton program Reality Show "86" di NET., maka peneliti menduga adanya pengaruh terhadap sikap berkendara di dalam kehidupan sehari-hari.

Berdasarkan penjelasan di atas maka tujuan dari penelitian ini adalah untuk mengetahui sikap penonton yang terbentuk tentang kepatuhan akan rambu-rambu lalu lintas, setelah menonton program ini. Oleh sebab itu maka penelitian ini akan berjudul "Pengaruh Program Reality Show Kepolisian Terhadap Sikap Penonton Di Jakarta (Studi tentang segmen lalu lintas dalam program " 86 " di NET.)".

\section{B. Landasan Teori}

Di dalam menyusun instrumen penelitian dan menganalisis hasil penelitian, digunakan Teori Kognitif Sosial. Teori ini merupakan pengembangan dari teori pembelajaran sosial (Social Learning Theory) dari Albert Bandura. Jika teori Social Learning mengatakan bahwa manusia belajar berperilaku dari lingkungan sosialnya (keluarga, teman bermain, dll). Maka, teori Kognitif Sosial (Social Cognitive Theory) khusus membandingkan tentang begaimana khalayak belajar dari media utamanya yaitu, televisi.

Teori Sosial Kognitif memiliki konsep utama yang disebut dengan Observational Learning. Observational Learning adalah dimana seseorang mempelajari perilaku dari seorang. Hal tersebut adalah modeling, yang berarti dimana seseorang mereproduksi perilaku secara langsung dan mekanis. Siapa pun bisa menjadi model untuk dipelajari sikap dan perilakunya, contohnya adalah artis, orang tua, teman, dan lain-lain (Baran, S. J., \& Davis, 2012).

Inhibition Effect adalah ketika seseorang mengamati perilaku model dan perilaku model tersebut mendapatkan hukuman, maka pengamat cenderung untuk mengurani perilaku yang model lakukan tersebut. Berbandi terbalik dengan Disinhibition Effect. Sedangkan Disinhibition Effect adalah pengamat memperagakan perilaku model karena model tersebut mendapatkan penghargaan seperti halnya seorang pengamen jalanan. Pengamen tersebut memiliki suara yang merdu dan mendapatkan tawaran untuk mengikuti kontes Indonesian Idol. Maka pengamat cenderung mengikuti perilaku sang model tersebut (Baranowsky, T., Perry, C. L., \& Parcel, 1997).

Konsep teori Sosial Kognitif lainnya adalah Self-Efficacy. Self-Efficacy adalah dimana seorang pengamat cenderung yakin dengan apa yang akan ia lakukan. Contohnya adalah seseorang melihat dan mengamati perilaku model di media televisi. Namun orang tersebut sudah tahu terhadap sikap yang sudah ia miliki (Bandura, 1999).

Untuk membangun instrument penelitian juga digunakan konsep Sikap. Sikap adalah suatu respon dari kesiapan seseorang yang bersifat positif dan negatif terhadap objek atau situasi secara konsisten. Pendapat ini memberikan gambaran bahwa sikap merupakan respon terhadap objek atau situasi yang disertai dengan adanya perasaan tertentu dan memberi dasar kepada orang tersebut untuk membuat respon atau perilaku dengan cara tertentu yang dipilihnya (Ahmadi, 2009). 
Konsep Sikap memiliki 3 komponen, yaitu : (1) Komponen Kognitif yaitu merupakan pengentahuan dan persepsi berdasarkan kombinasi pengalaman langsung dengan obyek sikap dan informasi yang berkaitan dari berbagai sumber yang diperoleh. Persepsi dan pengetahuan yang ditimbulkan bersifat kepercayaan penonton bahwa obyek sikap mempunyai berbagai sifat bahwa perilaku tertentu dapat menimbulkan hasil-hasil tertentu. (2) Komponen afektif merupakan perasaan emosi penonton kepada model di media televisi. Emosi yang dimaksud adalah sikap selektif dalam menilai sikap terhadap model di media secara langsung dan menyeluruh (sikap baik maupun tidak baik). (3) Komponen Konatif/Behavioural dalam sikap menunjukkan bagaimana perilaku atau kecenderungan berperilaku yang ada dalam diri seseorang berkaitan dengan sikap yang telah diamati. Asumsi dasar adalah bahwa perasaan mempengaruhi perilaku, karena itu, adalah logis untuk mengharapkan bahwa sikap seseorang akan dicerminkannya dalam bentuk perilaku terhadap objek yang ia pelajari (Azwar, 2015).

Konsep utama lainnya yang digunakan dalam penelitian ini adalah Konsep reality show, sebab variable X pada penelitian ini adalah Program Reality Show "86" di NET. Seperti yang dilansir dari situs resmi NET. pada tahun 2014 program Reality Show "86" di NET. mulai ditayangkan di televisi. Program yang menampilkan adegan yang memicu adrenalin ini menyuguhkan rasa dan isi media atau konten yang berbeda karena mengangkat sosok polisi beserta kinerjanya sebagai pengayom masyarakat menjadi materi tayangannya. Dalam tayangannya itu, aktivitas keseharian Polisi dalam menjaga ketertiban, keamanan dan melindungi masyarakat dari tindakan kejahatan inilah yang diekspos dan ditayangkan.

Dalam reality show ini terdapat beberapa segmen salah satunya adalah segmen lalulintas yang menampilkan bagaimana para pengendara yang mematuhi rambu lalu lintas dan juga yang tidak mematuhi rambu lalulintas. Dalam segmen ini ditampilkan sosok polisi, pengendara dan juuga info atau materi tentang pelanggaran yang akan diberi sanksi dan juga apresiasi pada pengendara yang patuh pada rambu lalu lintas. Oleh sebab itu dalam penelitian ini, program reality show ini akan mengukur dimensi polisi, pengendara dan info/materi,

Dalam membuat penelitian ini, ada beberapa riset yang menjadi panduan bagi peneliti untuk menghasilkan sebuah desain penelitian. Riset pertama adalah untuk melihat penerapan teori sosial kognitif dalam penelitian, dimana dikatakan bahwa untuk pembentukan perilaku termasuk sikap paling baik adalah dengan belajar dari role model dan sikap dan perilaku yang terbentuk itu adalah karena pertimbangan kognitif dari orang yang mempelajari sikap sang model (Alfaiz, A., Hariko, R., Zulfikar, Z., \& Suarja, 2017).

Penelitian kedua yang menjadi rujukan adalah tentang cara membuat instrumen sikap, dimana dikatakan bahwa pengukuran sikap sering dibedakan antara dimensi kepercayaan atau kognitif, perasaan atau afektif, dan kecenderungan perilaku atau konatif. Komponen kognitif adalah pernyataan kepercayaan terhadap obyek sikap, misalnya kepercayaan bahwa tindakan melanggar lalu lintas akan mendapatkan hukuman, sementara tindakan mematuhi lalu lintas akan mendapatkan penghargaan. Komponen afektif adalah menyusun pernyataan perasaan yang sangat langsung terhadap obyek sikap, misalnya penonton senang belajar dari program reality show bagaimana mematuhi peraturan lalu lintas akan menyelamatkan jiwa. Sedangkan komponen konatif menyatakan kecenderungan berperilaku dengan memperhatikan obyek, misalnya penonton akan belajar mematuhi peraturan lalu lintas dan memraktekannya dalam kehidupan sehari-hari (Gayatri, 2004).

Penelitian ke tiga yang menjadi rujukan juga menggunakan komponen sikap yang terdiri dari komponen Kognitif, Afektif dan Konatif, juga menjadi rujukan penelitian ini (Mahesthi, 2017).

Teori Kognitif Sosial sendiri berasumsi bahwa khalayak belajar melalui lingkungan yang dalam hal ini adalah media, utamanya televisi. Dalam memelajari apa yang ada dalam konten media, khalayak melakukan 5 hal yaitu Observational Learning Effect, Response Facilitation Effect, Response Inhibition Effect, Response Disinhibition Effect, dan Self Efficacy. Setelah melalui ke lima tahap ini maka akan terbentuk sebuah Sikap dari Penonton tentang isi media yang dikonsumsinya.

Oleh sebab itu hipotesis penelitian dari penelitian ini adalah diduga ada pengaruh program reality show "86" terhadap Sikap Penonton dalam mematuhi peraturan lalulintas. 
Hipotesis ini diformulasikan sebagai berikut:

Ha: Diduga ada pengaruh program reality show "86" terhadap Sikap Penonton dalam mematuhi peraturan lalulintas.

Ho: Diduga tidak ada pengaruh program reality show "86" terhadap Sikap Penonton dalam mematuhi peraturan lalulintas.

Dari hipotesis penelitian maka akan diformulasikan ke hipotesis statistik yaitu sebagai berikut:

$$
\begin{aligned}
& \mathrm{Ha}=\mathrm{R}^{2} \mathrm{XY}>0 \\
& \mathrm{Ho}=\mathrm{R}^{2} \mathrm{XY}<0 \text { atau } \mathrm{R}^{2} \mathrm{XY}=0
\end{aligned}
$$

\section{Hasil Penelitian dan Pembahasan}

Dari 100 responden yang didapatkan, jenis kelamin yang terbanyak adalah laki - laki dengan $76 \%$ maka jumlah laki-laki yang mengisi kuesioner ini lebih banyak dibandingkan perempuan. Karakteristik responden berdasarkan usia yang terbanyak adalah berusia $>19-24$ tahun dengan presentase 53\%. Karakteristik responden berdasarkan domisili yang terbanyak adalah Jakarta Selatan dengan presentase $76 \%$. Karakteristik responden berdasarkan pengeluaran/perbulan yang terbanyak adalah < Rp. 500.000 berjumlah 32 orang atau presentase $32 \%$, karakteristik responden berdasarkan profesi/pekerjaan yang terbanyak adalah Mahasiswa berjumlah 40 orang atau presentase $40 \%$.

Dari hasil penelitian Univariat dari beberapa dimensi mengenai Variabel program Reality Show "86" di NET. (X) terhadap Sikap (Y) dapat diketahui bahwa tingkat persetujuan tertinggi dari semua dimensi yaitu dimensi Afektif memiliki nilai rata-rata tertinggi 462 bahwa tingkat persetujuan responden berada di tingkat Setuju dan terendah terletak pada Dimensi Pengendara memiliki nilai rata-rata terendah 434,4 bahwa tingkat persetujuan responden berada ditingkat Ragu-ragu mendekati setuju.

Pada hasil analisis Bivariat menunjukkan nilai R (koefision korelasi) sebesar 0,869 yang berarti terdapat hubungan yang sangat kuat antara variabel program Reality Show "86" di NET. (X) dan variabel Sikap (Y). sementara nilai R2 (R Square) atau disebut sebagai koefisien Determinasi menunjukkan nilai sebesar 77,5\% yang artinya terdapat pengaruh variabel program Reality Show "86" di NET. (X) terhadap variabel Sikap (Y) sangat signifikan yaitu sebesar 77,5\% Karena nilai R2 lebih dari 50\%. Sementara sebesar 22,5\% pengaruh pada Sikap penonton disebabkan oleh variabel-variabel lain yang tidak diteliti dalam penelitian ini. Hasilnya dapat dilihat dalam Tabel 3 di bawah ini:

Tabel 3. Pengaruh Program Reality Show " 86 " terhadap Sikap Penonton di Jakarta dalam Mematuhi Rambu Lalu Lintas

\begin{tabular}{l|r|r|r|r|}
\hline Model & $\mathrm{R}$ & $\mathrm{R}$ Square & $\begin{array}{c}\text { Adjusted R } \\
\text { Square }\end{array}$ & $\begin{array}{r}\text { Std. Error of } \\
\text { the Estimate }\end{array}$ \\
\hline 1 &, $869^{\mathrm{a}}$ &, 755 &, 753 &, 20231 \\
\hline
\end{tabular}
a. Predictors: (Constant), Program Reality Show "86" di
NET.

Sumber: Hasil Penghitungan SPSS, 2019

\section{Kesimpulan}

Terdapat pengaruh yang sangat signifikan dari variabel Program Reality Show "86" di NET. (X) terhadap Variabel Sikap (Y) dari para responden pada penelitian ini. Hubungan di antra kedua variable juga sangat kuat.

Selain itu, teori Sosial Kognitif yang digunakan dalam penelitian ini memiliki kecocokan yang membuat hasil dari Pengaruh Program Reality Show "86" di NET. (X) terhadap Sikap (Y) menjadi signifikan.

Hal ini membuktikan bahwa teori Sosial Kognitif sangat tepat digunakan pada penelitian ini yang berjudul "Pengaruh Program Reality Show Kepolisian Terhadap Sikap 
Penonton, Khususnya Para Pengendara Di Jakarta Dalam Mematuhi Rambu Lalu Lintas (Studi tentang segmen lalu lintas dalam program "86" di NET.)".

\section{Daftar Pustaka}

[1] Ahmadi, A. (2009). Psikologi Sosial. Rineka Cipta.

[2] Alfaiz, A., Hariko, R., Zulfikar, Z., \& Suarja, S. (2017). Perspektif Teori Kognitif Sosial dan Psikosintesis dalam Membentuk Kepribadian. In C. I. Gunawan, BUKU BUNGA RAMPAI(Kumpulan Karya Dosen Seluruh IndonesiaBidang Ilmu-ilmu Sosial dan Ilmuilmu Eksakta Tahun 2017. CV IRDH.

[3] Andriyarini, T. (2014). Program Reality Show "86" Hadir Temani Pemirsa NET. TV. Retrieved from KapanLagi.Com. https://www.kapanlagi.com/showbiz/televisi/programreality-show-348634-hadir-temani-pemirsa-net-tv-9175b2.html

[4] Arafat, L. O. M. (2021). Peran Komusi Penyiaran Indonesia dalam Pelaksanaan Siaran Program Talkshow.

[5] Azwar, S. (2015). Sikap Manusia Teori dan Pengukurannya. Pustaka Pelajar.

[6] Bandura, A. (1999). Self-Efficacy in Changing Society. Cambridge. Cambridge University Press.

[7] Baran, S. J., \& Davis, D. K. (2012). Mass Communication Theory: Foundations, Ferment, and Future. Belmont. Wadsworth.

[8] Baranowsky, T., Perry, C. L., \& Parcel, G. S. (1997). How Individuals, environments, and health behavior interact: Social Cognitive Theory. In K. Glanz, F. M. Lewis, \& B. K. Rimer, Health Behavior and Health Education: Theory, Research, and Practice. 2nd edition. Wiley.

[9] Bryman, A. (2012). ). Social Research Methods 4th Edition. Oxford University Press.

[10] Darajat, I. R. (2017). Memoles Citra Polisi di Televisi. Retrieved from Remotivi.Co.Id. http://www.remotivi.or.id/amatan/377/memoles-citra-polisi-di-televisi

[11] Fachruddin, A. (2015). Cara Kreatif Memproduksi Program Televisi. CV Andi Offset.

[12] Gayatri, D. (2004). Mendesain Instrumen Pengukuran Sikap. Jurnal Keperawatan Indonesia. Volume 8, 76-80.

[13] Gunsyahputra, A. (2020). Pengaruh Program Acara Televisi Terhadap Pemenuhan Kebutuhan Informasi.

[14] Kriyantono, R. (2014). Teknik Praktis: Riset Komunikasi. Kencana Pernada Media Group.

[15] Lumbanraja, S. (2014). '86’ Hati-hati Melanggar Hukum Anda Masuk TV. Retrieved from Kompasiana.Com.

https://www.kompasiana.com/sahroha.lumbanraja/54f4b3647455137e2b6c8f44/86hatihati-melanggar-hukum-anda-masuk-tv

[16] Mahesthi, A. P. (2017). Sikap Masyarakat Surabaya Terhadap Iklan Air Asia “We'll Take You There." Jurnal E-Komunikas, VOL 5. NO., 1-12.

[17] Morissan, M. (2018). Manajemen Media Penyiaran Strategi Mengelola Radio \& Televisi. Prenada Media.

[18] Nielsen. (2019). Hasil Riset AGB Nielsen. AGB Nielsen.

[19] Riduwan. (2013). Metode Dan Teknik Menyusun Tesis. Alfabeta.

[20] Singarimbun, M., \& Effendi, S. (2006). Metode Penelitian Survei. : PT. Pustaka LP3S, Jakarta. 